\title{
A qualitative study on the problems encountered by secondary school students on the net
}

\author{
Lale TORAMAN \\ ICT Teacher, Ereğli Şehit Ömer Halisdemir Middle School, Konya, Turkey
}

\begin{abstract}
Ertuğrul USTA*
Department of Computer Education and Instructional Technologies, Necmettin Erbakan University, Konya, Turkey
\end{abstract}

\begin{tabular}{|c|c|}
\hline Articl & ed to use of the \\
\hline $\begin{array}{l}\text { Received: } \\
18.11 .2018\end{array}$ & $\begin{array}{l}\text { internet and the problems that they are faced on the internet were } \\
\text { investigated. In this context students' and parents' views related to the use }\end{array}$ \\
\hline $\begin{array}{l}\text { Received in revised form: } \\
01.12 .2018\end{array}$ & $\begin{array}{l}\text { of internet by secondary school students were examined. In this study, } \\
\text { qualitative researching method was used. This study was applied to } \\
\text { secondary school students and parents in } 2016-2017 \text { educational years. }\end{array}$ \\
\hline $\begin{array}{l}\text { Accepted: } \\
04.12 .2018\end{array}$ & $\begin{array}{l}\text { As collecting data tool; "Personal Information Form" and "Semi- } \\
\text { Structured Interview Form" were used. Content analysis technique was }\end{array}$ \\
\hline Key words: & lysis of data. According to the results obtained from the \\
\hline $\begin{array}{l}\text { Internet usage; students' views; } \\
\text { parents' views; secondary } \\
\text { school students; information } \\
\text { technologies }\end{array}$ & $\begin{array}{l}\text { research, the following data has been reached. A high percentage of the } \\
\text { students involved in the research }(79,16 \%) \text { know nothing about the } \\
\text { cyberbullying and the things to be done within their rights when } \\
\text { encountered with it. } 31,5 \% \text { of them use the net to study or do homework, } \\
20,5 \% \text { for social networking sites and } 17,1 \% \text { to play online games. It } \\
\text { was also concluded that the most common problem encountered is the } \\
\text { messages and demands from the people they do not know, in which case } \\
\text { the parents know somehow and tend to solve the problem by taking } \\
\text { necessary precautions, filing a petition or taking action legally. }\end{array}$ \\
\hline
\end{tabular}

\section{Introduction}

With the development of information and communication technologies and the widespread use in daily life, such as in every area, bullying has also begun to take place in virtual environments. It has become easier to be bully or bully-victim in various forms on the internet via mobile phones, social networks, chat rooms or websites. As a result of rapid development and changes in technology, cyberbullying has emerged. For cyberbullying can be defined as the realization of bullying behaviors using technology. Tokunaga (2010) stated that cyberbullying is related to similar concepts such as online harassment, online bullying, and electronic bullying and includes these concepts. The broadest definition of cyberbullying; is the realization of intentional and repetitive behavior by means of information and communication technologies by an individual or group to harm others (Blais, 2008). Some definitions of cyberbullying are as follows: Cyberbullying is an aggression by means of electronic with ridicule, insults, threats, harassment or intimidation (Raskauskas and Stoltz,

*Correspondence:ertugrulusta@gmail.com 
2007). Cyberbullying; in a chat room or on a web page, via email, instant messaging, or messages or pictures sent to a mobile phone (Kowalski and Limber, 2007). Cyberbullying is one of the things that someone else is teasing online, messaging with someone over the phone or messaging repeatedly, or sending messages that they do not like (Hinduja and Patchin, 2011). Cyberbullying is the use of someone's photo or personal information to hurt, shrink or ridicule a person (Holla, 2013). Cyberbullying; that an individual or a group by using information and communication technologies to send another person or group by cruel text or graphics, to constantly and intentionally threaten and harass (Mason, 2008). Cyberbullying is an opportunistic crime because it damages without physical communication, requires very little planning, and the risk of getting caught is small (Englander and Muldowney, 2007). Cyberbullying involves the use of tools of information and communication technology to destroy information and damage personal sites (Q. Li, 2007a). Using cyberbullying, information and communication technologies, an individual or a group is deliberately, repeatedly or unintentionally attempting to harm all technical or relational damaging behaviors and information and communication technologies such as electronic mail, cell phones, pagers, text messaging services, websites, (Tanrıkulu, Kınay and Arıcak, 2013). Cyberbullying is the result of deliberate, aggressive and repetitive behaviors against the victim, malicious use of mobile phones, computers and other technological devices as a result of changes in technology in recent years (Steffgen and König, 2009). In cyberbullying behavior; behaviors such as naming, humiliating, making rumors about, ridiculing, making bad jokes, writing bad things about someone can be seen (Manap, 2012).

Cyberbullying people think that other people are also in cyberbullying behaviors and believe that these behaviors are acceptable. Cyberbullying affects negatively the cyber victims (Brown, Jackson and Cassidy, 2006). The results from some studies also support this: Many cyber bullies said that exposed cyberbullying (Baker and Kavşut, 2007; Görzig and Frumkin, 2013; Q. Li, 2007a). Cyberbullying usually occurs due to problems between the victim and the bully (Akbulut and Eriști, 2011). Li (2007b) stated that in the study 15\% of the students exposed to peer bullying. As a result of the end of emotional relations, cyberbullying is done with the feeling of revenge (Özdemir and Akar, 2011). They reported that $39 \%$ of cyberbullied people were taking revenge, $26 \%$ for making jokes, $16 \%$ for frying things, $15 \%$ for bullying and cyberbullying behaviors (Cross, Piggin, Douglas and Vonkaenel-Flatt, 2012). Dilmaç (2009) states that approximately one-fourth of university students have been cyberbullying at least once, and half of them have been subjected to cyberbullying at least once in their lives.

When we look at the definitions about cyber bullying, we can describe the concept of cyber bullying as repetitive using the internet and telecommunication technologies. As it can be seen in the definitions, the basic elements of cyberbullying are related to information and communication technologies. Kowalski, Limber and Agatston (2008) described cyberbullying as an electronic concept of face to face bullying rather than a separate concept. It can be said that the realization of bullying in virtual environments does not require being strong in technical skill as it is in face-to-face bullying, but cyberbullying behaviors like sending a false message with computers or mobile phones do not require superior technical skills. The most important feature of cyber bullying is that there is no possibility of escape from the victim (Slonje and Smith, 2008).

\section{Research topic}

With the increase of the internet in our lives and the fact that the students of the new millennium are inside the internet, the problems that students experience in the web environment have also increased. The widespread use of the Internet, smartphones and social 
networks and the fact that they reach very young ages cause those who face problems on the web to reach their young age. In this context, it is thought that it is important for middle school students to examine their opinions about internet usage and the problems they encounter on the internet environment and to contribute to the work done in this field. In this research, "Secondary School Students' Internet Use and Encountered Problems" was set as a research topic.

\section{Purpose of the research}

The purpose of this research is to determine the opinions of middle school students and their parents about the internet usage of students and the problems they encounter on the internet.

\section{Problem}

Problem statement of this research: "Secondary School Students' Internet Uses and What Are the Problems They Encounter on the Net?"

(1) What are the opinions of parents about the internet use of middle school students?

(2) What are the opinions of the students regarding the problems they face in the internet environment?

\section{Method}

\section{Research method}

The qualitative research design is used in this study. A semi-structured interview technique was used to collect the data.

\section{Participants}

The study group of the research consisted of 24 students who were educated in the $5^{\text {th }}$, $6^{\text {th }}, 7^{\text {th }}$ and $8^{\text {th }}$ grades and selected by random sampling and 12 parents selected by random sampling from the parents of these students in Ereğli, Konya.

\section{Data Collection Tools}

A semi-structured interview form was used to collect the data. For this, interview questions were prepared and expert opinions were taken and converted into interview form and applied to students and parents.

\section{The Data Analysis}

Content analysis method was used to analyze the data. The main purpose of the content analysis is to reach concepts and associations that can explain the data. Therefore, the collected data should be conceptualized first, and then the themes should be organized in a logical way according to the emerging concepts and to explain the data (Yıldırım and Şimşek, 2013). In the content analysis, the related categories are determined and the analyzed data are grouped according to the identified categories (Özdemir, 2010). In the analysis of data, the content analysis method is used in analyzing qualitative data; coding of data, finding of themes, the arrangement of codes and themes, and identification and interpretation of the findings (Yıldırım and Şimşek, 2013).

In this study, the answers given by the parents and students in the two study groups to the interview questions were coded and the themes were formed. Accordingly, the obtained data 
were grouped and interpreted. In addition, 2 - 3 of the answers given for each interview question were presented exactly. The actual names of parents and students in the study group were not used when the data were presented and the findings were interpreted. Each of the interviewed parents was given the following codes: K1, K2, K3 ... K12. Each of the students interviewed was given the codes Ö1, Ö2, Ö3 ... Ö24. Findings obtained in the research were presented and interpreted respectively according to the questions in the interview form.

\section{Findings}

In this section, the answers given by the students and their families to the interview questions in the direction of the research purpose were examined and analyzed by the content analysis method and interpreted.

\section{Findings related to the first sub problem (What are the opinions of the parents about the internet use of middle school students?)}

The interview questions are as follows:

(1) Did you know the concept of cyberbullying? Have you heard from the press, television or social media before?

(2) What do you think about your child's use of the internet, what are your opinions?

(3) What purpose and how does your child use the internet?

(4) Is the computer in your home shared in the child's own room?

(5) Do you use secure internet service that offers child/family profile? Why?

(6) Do you check your child's computer and internet usage?

(7) Are you checking your child's daily computer usage?

(8) Do you track which sites your child enters or plays?

(9) Does your child know or use educational content sites?

(10) Do your children know about the problems they face on the internet?

(11) What do you do if your child encounters cyberbullying via social media?

(12) Do you come to see the problem or try to solve it yourself, do you seek legal ways?

The answers to the interview questions were examined and the codes were created and categorized.

Table 1. The views of parents about the internet use of secondary school students

\begin{tabular}{|c|c|c|c|}
\hline Category & Main Theme & Sub Theme & Frequency \\
\hline \multirow{4}{*}{ Know Cyberbullying } & \multirow[b]{2}{*}{ Yes } & From social media & 1 \\
\hline & & \multirow[t]{3}{*}{ Other } & 6 \\
\hline & No & & 5 \\
\hline & Total & & 12 \\
\hline \multirow{13}{*}{ Internet Using } & \multirow{5}{*}{ Frequency of use } & Little & 2 \\
\hline & & Enough & 3 \\
\hline & & When it's necessary, controlled & 2 \\
\hline & & Very & 5 \\
\hline & & Homework & 4 \\
\hline & \multirow{5}{*}{ Purpose of use } & Lessons & 7 \\
\hline & & Research & 4 \\
\hline & & Game & 9 \\
\hline & & Video / music & 3 \\
\hline & & Social media / chat & 10 \\
\hline & \multirow{2}{*}{ Opinion } & $\begin{array}{l}\text { Education/use is incorrect find except } \\
\text { for education }\end{array}$ & 2 \\
\hline & & Use of social media is very & 2 \\
\hline & Total & & 53 \\
\hline
\end{tabular}




\begin{tabular}{|c|c|c|c|}
\hline Computer Environment & $\begin{array}{c}\text { No computer } \\
\text { In the child's room } \\
\text { In common use area } \\
\text { Total }\end{array}$ & & $\begin{array}{c}3 \\
2 \\
7 \\
12 \\
\end{array}$ \\
\hline \multirow{6}{*}{ Secure Internet Use } & \multirow{3}{*}{ Use } & For cyber security & 1 \\
\hline & & For to protect & 2 \\
\hline & & Other & 2 \\
\hline & \multirow{2}{*}{ Not use } & Doing too much restraint & 1 \\
\hline & & Other & 6 \\
\hline & Total & & 12 \\
\hline \multirow{4}{*}{ Internet Usage Control } & Checking & & 7 \\
\hline & Not checking & $\begin{array}{c}\text { He/She is able to control } \\
\text { Other }\end{array}$ & $\begin{array}{l}1 \\
2\end{array}$ \\
\hline & Time to time & & 2 \\
\hline & Total & & 12 \\
\hline \multirow{7}{*}{$\begin{array}{c}\text { Computer Usage Time } \\
\text { Control }\end{array}$} & \multirow{4}{*}{ Yes } & Daily half an hour & 1 \\
\hline & & For extracurricular use & 1 \\
\hline & & Using at weekends & 1 \\
\hline & & Other & 5 \\
\hline & \multirow{2}{*}{ No } & No computer & 1 \\
\hline & & Other & 3 \\
\hline & Total & & 12 \\
\hline \multirow{4}{*}{ Websites Usage Control } & \multirow{2}{*}{ Yes } & Most of the time & 1 \\
\hline & & Other & 7 \\
\hline & No & & 4 \\
\hline & Total & & 12 \\
\hline \multirow{4}{*}{$\begin{array}{l}\text { Know / Use Educational } \\
\text { Websites }\end{array}$} & Don't know & & 1 \\
\hline & \multirow{2}{*}{ Yes } & He/She know & 6 \\
\hline & & He/She use & 5 \\
\hline & Total & & 12 \\
\hline \multirow{5}{*}{ Be Aware of Problems } & Yes & & 7 \\
\hline & \multirow{2}{*}{ No } & $\mathrm{He} / \mathrm{She}$ is solving & 1 \\
\hline & & Other & 2 \\
\hline & Sometimes & & 2 \\
\hline & Total & & 12 \\
\hline \multirow{12}{*}{$\begin{array}{l}\text { Reaction to } \\
\text { Cyberbullying }\end{array}$} & \multirow{6}{*}{ Prevention } & To obstacle & 2 \\
\hline & & Restriction of use & 1 \\
\hline & & Warning & 2 \\
\hline & & Closing Accounts & 1 \\
\hline & & Take prevention & 3 \\
\hline & & Prosecute & 1 \\
\hline & \multirow{2}{*}{ Complain } & Reporting to the police & 1 \\
\hline & & To complain & 4 \\
\hline & $\begin{array}{l}\text { Consultation with } \\
\text { experts }\end{array}$ & & 1 \\
\hline & To the child & & 1 \\
\hline & Try to solve & & 1 \\
\hline & Total & & 18 \\
\hline \multirow{6}{*}{ Problem Solving } & Legal remedies & & 9 \\
\hline & Ignore & Can solve & 1 \\
\hline & Try to solve myself & & 1 \\
\hline & Expert assistance & & 1 \\
\hline & Don't know & & 2 \\
\hline & Total & & 14 \\
\hline
\end{tabular}


After the interview with parents, the answers were given are coded and Know Cyberbullying, Internet Using, Computer Environment, Secure Internet Use, Internet Usage Control, Computer Usage Time Control, Websites Usage Control, Know / Use Educational Websites, Be Aware of Problems, Reaction to Cyberbullying and Problem Solving categories were created. The data were grouped according to categories and main themes and sub-themes were created. The frequencies and interpretations of the themes and sub-themes of the generated categories are as follows:

It is observed that the number of people who know the concept of cyberbullying is 12 and the number of people who do not know the concept of cyberbullying is 5 .

Some answers about knowing the concept of cyberbullying are as follows:

"I know. I heard from social media." (K3)

"No. I do not have any knowledge." (K8)

"I know I heard it." (K12)

When looking at the 37 answers that in the Purpose of use main theme, the two most preferred sub-themes are seen Social Media / Chat $(n=10)$ and Game $(n=9)$ sub-themes.

Some of the answers given by parents on internet usage of their children are as follows:

"He spends a lot of time on social media." (K2)

"If we do not take the necessary precautions, they kill too much time on the Internet."

"He's spending a lot of time. I find it wrong to enter different programs except for education." (K9)

"Sometimes he plays, he does his homework." (K1)

"Using for education, social media and entertainment." (K12)

According to the Computer Environment category, 7 out of 12 answers show that the computer at home is in the common area.

Here are some of the answers given about the location of the computer at home:

"No computer" (K5)

"In the child's own room" (K7)

"In common use" (K12)

When we looked at a total of 12 couples in the Secure Internet Use category, 7 people stated that they did not use secure internet service and 5 people stated that they use secure internet service.

Some of the answers to the situation of using secure internet are as follows:

"No, I do not." (K1)

"Yes. Because I think it will be more harmful if the internet is not used safely." (K4)

"I use" (K8)

When we look at 12 frequencies in the Internet Usage Control category, we can say that 9 parents control their children's computer and internet usage.

Some of the answers given to the situation about control their children's use of the internet are as follows:

"Time to time. He informs me about his games." (K4)

"Yes. We are checking." (K8)

"I check it occasionally." (K12)

When we look at a total of 12 frequencies in the Computer Usage Time Control category, we 
can say that 8 parents control the duration of their children's computer use. Some of the answers about controlling the child's computer use period are as follows:

"Weekends use 1 or 3 hours" (K1)

"No" (K5)

"Yes. We take precautions not to exceed a half-hour per day." (K8)

When we look at a total of 12 frequencies in the Websites Usage Control category, we can say that 8 parents controlled their children which have entered a website or which games they play.

Some of the answers given to follow up about which sites their children enter are:

"I do not follow." (K2)

"I often try to follow the games." (K4)

When we look at a total of 12 frequencies in the Know / Use Educational Websites category, 11 people stated that the child knows and uses educational content sites. 1 person stated that the child does not know educational content sites.

Some of the answers about the child's knowledge and use of educational content sites are as follows:

"I do not know" (K1)

"Yes." (K3)

"He knows and uses it." (K8)

When we look at a total of 12 frequencies in the Be Aware of Problems category, we can say that 9 children are aware of the problems they face on the internet. Some of the answers given by the parents about their children's awareness of the problems they face on the internet are as follows:

"No" (K2)

"Usually" (K3)

"I have not had a problem until now, but I think if we do, I will be informed." (K4)

When looking at a total of 18 frequencies in the Reaction to Cyberbullying category, half of the responses $(n=9)$ seems to be in the prevention main theme. Some of the answers given by the parents about their children's reactions when they encountered cyberbullying are as follows:

"I complain." (K2)

"Leave your son because he knows what to do." (K7)

"I take the necessary precautions in consultation with experts." (K8)

When looking at a total of 14 frequencies in the Problem Solving category, the majority of the parents $(n=9)$ seems to have chosen to resort to legal remedies. Some of the answers parents about to solve the problems their children encounter are:

"I do not know" (K1)

"I apply for legal remedies." (K4)

"As soon as we are not insensitive, we get legal help from specialists." (K8)

\section{Findings related to the Second Sub problem (What are the opinions of the students on the Internet in relation to the problems?)}

The interview questions are as follows:

(1) Did you know the concept of cyberbullying? Did you hear from the press, on television or on social media?

(2) When and how did you learn to use computer and internet? 
(3) What purpose and how do you benefit from the Internet?

(4) Do you use the internet to read newspapers/magazines?

(5) What are the problems you face when using computers and internet?

(6) How do you find solutions to problems you encounter while using computer and internet?

(7) What problems do you face on social media platforms?

(8) Did you compare cyberbullying with social media?

(a) Have you shared a photograph/video that you did not want/tagged without permission? What did you do?

(b) Have you received disturbing messages or comments? How were they?

(c) Are there mockers in the social media environment? What did you do?

(d) Have you been exposed to insulting language on the internet? By whom and how?

(e) Has it taken over the social media account or has it happened to someone else? Is there anything you hear/feel about it?

(9) What did you feel and what you did if you were facing cyberbullying?

(10) What do you do if you experience cyberbullying? Do you know your rights?

(11) Do you complain about the cyberbully? Where do you go?

The answers to the interview questions were examined and the codes were created and categorized.

Table 2. Students' views about the problems they face in the internet environment

\begin{tabular}{|c|c|c|c|}
\hline Category & Main Theme & Sub Theme & Frequency \\
\hline \multirow{4}{*}{ Know Cyberbullying } & \multirow[b]{2}{*}{ Yes } & From social media & 2 \\
\hline & & \multirow[t]{3}{*}{ Other } & 3 \\
\hline & No & & 19 \\
\hline & Total & & 24 \\
\hline \multirow{15}{*}{$\begin{array}{c}\text { Computer and Internet } \\
\text { Learning }\end{array}$} & \multirow{8}{*}{ Learning time } & 4 years old & 2 \\
\hline & & 5-6 years old & 9 \\
\hline & & 7 years old & 5 \\
\hline & & $8-9$ years old & 5 \\
\hline & & 10 years old & 3 \\
\hline & & Mother & 2 \\
\hline & & Father & 7 \\
\hline & & Sister & 2 \\
\hline & \multirow{6}{*}{$\begin{array}{l}\text { Learned person / } \\
\text { status }\end{array}$} & Brother & 2 \\
\hline & & Researching & 3 \\
\hline & & With play & 2 \\
\hline & & Cousins & 4 \\
\hline & & Uncle & 1 \\
\hline & & Teacher & 1 \\
\hline & Total & & 48 \\
\hline \multirow{8}{*}{$\begin{array}{c}\text { Purpose of Internet } \\
\text { Usage }\end{array}$} & \multirow{5}{*}{ Education } & Homework & 13 \\
\hline & & Lesson & 3 \\
\hline & & Research & 5 \\
\hline & & E-school & 1 \\
\hline & & Game & 11 \\
\hline & \multirow[t]{2}{*}{ Entertainment } & Video / movie viewing & 9 \\
\hline & & Social media & 8 \\
\hline & Total & & 50 \\
\hline Reading & Yes & & 2 \\
\hline Newspaper/Journal & No & & 22 \\
\hline from The Internet & Total & & 24 \\
\hline
\end{tabular}




\begin{tabular}{|c|c|c|c|}
\hline \multirow{8}{*}{ Problems Encountered } & \multirow{3}{*}{ Hardware } & Internet & 7 \\
\hline & & Keyboard & 1 \\
\hline & & Viruses & 4 \\
\hline & Malwares & Advertisements & 8 \\
\hline & $\begin{array}{l}\text { Messages from } \\
\text { unknown contacts }\end{array}$ & & 2 \\
\hline & $\begin{array}{c}\text { Spend a lot of } \\
\text { time }\end{array}$ & & 1 \\
\hline & No problem & & 4 \\
\hline & Total & & 27 \\
\hline \multirow{10}{*}{$\begin{array}{l}\text { Solutions to Problems } \\
\text { Encountered }\end{array}$} & \multirow{2}{*}{ Internet } & By waiting & 2 \\
\hline & & Check the internet connection & 5 \\
\hline & Keyboard & Using voice keyboard & 1 \\
\hline & Viruses & Antivirus program & 2 \\
\hline & \multirow{2}{*}{ Advertisements } & Closing & 7 \\
\hline & & By complaining & 1 \\
\hline & $\begin{array}{l}\text { Messages from } \\
\text { unknown contacts }\end{array}$ & Put obstacle & 2 \\
\hline & $\begin{array}{c}\text { Spend a lot of } \\
\text { time }\end{array}$ & Turning of the computer & 1 \\
\hline & No problem & & 4 \\
\hline & Total & & 25 \\
\hline \multirow{10}{*}{ Social Media Problems } & \multirow{5}{*}{$\begin{array}{l}\text { Inappropriate } \\
\text { post/message }\end{array}$} & Swearing & 2 \\
\hline & & Slang & 2 \\
\hline & & Meaningless writings & 1 \\
\hline & & Bad message & 2 \\
\hline & & Messages from unknown contacts & 3 \\
\hline & \multirow{2}{*}{ Request } & Malicious accounts & 1 \\
\hline & & Request from unknown contacts & 3 \\
\hline & $\begin{array}{l}\text { I don't use social } \\
\text { media }\end{array}$ & & 4 \\
\hline & Didn’t encounter & & 11 \\
\hline & Total & & 29 \\
\hline \multirow{9}{*}{$\begin{array}{c}\text { Unauthorized } \\
\text { Photo/Video Sharing }\end{array}$} & \multirow{7}{*}{ It was } & I Complained & 3 \\
\hline & & I Blocked & 1 \\
\hline & & I warned & 2 \\
\hline & & Be angry & 1 \\
\hline & & I did spam & 2 \\
\hline & & I stole account & 1 \\
\hline & & Didn't anything & 2 \\
\hline & It was not & & 15 \\
\hline & Total & & 27 \\
\hline \multirow{7}{*}{$\begin{array}{c}\text { Receive an Irritating } \\
\text { Message }\end{array}$} & & Someone sends 300 messages & 1 \\
\hline & & Abusive sentences & 4 \\
\hline & I received & Moniker & 1 \\
\hline & & Redundant comments & 1 \\
\hline & & Messages from unknown contacts & 2 \\
\hline & I didn't receive & & 15 \\
\hline & Total & & 24 \\
\hline \multirow{6}{*}{$\begin{array}{l}\text { In Social Media } \\
\text { Mockery }\end{array}$} & \multirow{3}{*}{ It was } & Pound & 1 \\
\hline & & Didn't care & 1 \\
\hline & & Reported & 1 \\
\hline & \multirow{2}{*}{ It was not } & If it will, I block & 1 \\
\hline & & Other & 20 \\
\hline & Total & & 24 \\
\hline \multirow{3}{*}{ Internet Insulting } & \multirow{2}{*}{ Be exposed } & By my friend & 1 \\
\hline & & Comments on & 1 \\
\hline & Not be exposed & & 20 \\
\hline
\end{tabular}




\begin{tabular}{|c|c|c|c|}
\hline & $\begin{array}{c}\text { I haven't account } \\
\text { Total }\end{array}$ & & $\begin{array}{c}2 \\
24 \\
\end{array}$ \\
\hline \multirow{8}{*}{$\begin{array}{l}\text { Capture of Social } \\
\text { Media Account }\end{array}$} & \multirow{5}{*}{ Captured } & Changed password & 1 \\
\hline & & I did spam & 1 \\
\hline & & I Hacked & 1 \\
\hline & & Don't know & 1 \\
\hline & & Other & 5 \\
\hline & Not captured & & 12 \\
\hline & I haven't account & & 3 \\
\hline & Total & & 24 \\
\hline \multirow{3}{*}{$\begin{array}{c}\text { Encounter } \\
\text { Cyberbullying }\end{array}$} & I encountered & & 3 \\
\hline & I didn't encounter & & 21 \\
\hline & Total & & 24 \\
\hline \multirow{5}{*}{$\begin{array}{c}\text { Cyberbullying Result } \\
\text { Situation }\end{array}$} & \multirow{3}{*}{ Emotion } & Sad & 1 \\
\hline & & Feel bad & 2 \\
\hline & & Very sad & 1 \\
\hline & Action & Complained & 2 \\
\hline & Total & & 6 \\
\hline \multirow{3}{*}{$\begin{array}{c}\text { Situation to Know } \\
\text { Rights }\end{array}$} & I know & & 9 \\
\hline & I don't know & & 15 \\
\hline & Total & & 24 \\
\hline \multirow{6}{*}{$\begin{array}{l}\text { Response to } \\
\text { Cyberbullying }\end{array}$} & \multirow{5}{*}{ Action } & Pay attention & 1 \\
\hline & & Change account & 1 \\
\hline & & Counter & 8 \\
\hline & & Block & 4 \\
\hline & & Respond, spam & 1 \\
\hline & Total & & 15 \\
\hline \multirow{4}{*}{$\begin{array}{l}\text { Complain for Cyber } \\
\text { Bully }\end{array}$} & Yes & & 18 \\
\hline & No & & 5 \\
\hline & I didn't encounter & & 1 \\
\hline & Total & & 24 \\
\hline \multirow{11}{*}{ Place of Complaint } & \multirow{3}{*}{ Formal } & Court & 2 \\
\hline & & Police & 4 \\
\hline & & Related places & 4 \\
\hline & \multirow{2}{*}{ Family } & Tell brother & 1 \\
\hline & & I solve & 1 \\
\hline & \multirow{5}{*}{ Other } & Close account & 2 \\
\hline & & Block & 1 \\
\hline & & Encountered website & 2 \\
\hline & & Spam & 1 \\
\hline & & Don't know & 3 \\
\hline & Total & & 21 \\
\hline
\end{tabular}

After the interview with parents, the answers were given are coded and Know Cyberbullying, Computer and Internet Learning, Purpose of Internet Usage, Reading Newspaper/Journal from The Internet, Problems Encountered, Solutions to Problems Encountered, Social Media Problems, Unauthorized Photo/Video Sharing, Receive an Irritating Message, In Social Media Mockery, Internet Insulting, Capture of Social Media Account, Encounter Cyberbullying, Cyberbullying Result Situation, Situation to Know Rights, Response to Cyberbullying, Complain for Cyber Bully and Place of Complaint categories were created. The frequencies and interpretations of the themes and sub-themes of the generated categories are as follows:

It is seen that the number of students who know the concept of cyberbullying is 5 and the number of students who do not know is 19. It is observed that most students do not hear or know the concept of cyberbullying. Some answers about knowing the concept of cyberbullying are as follows:

"No. I did not know and did not hear." (Ö8) 
(Ö20)

"I heard it for the first time, but my guess is to bully while talking on the computer."

"No. I did not hear." (Ö24)

When we look at the frequencies of the sub-themes created in the Computer and Internet Learning main theme, it is seen that the majority of the students learned to use computer and internet at 5-6 years old $(n=9)$ from their fathers $(n=7)$. Some of the answers given by students about when and how to use computers and the internet are as follows:

"From my cousins in my 5-6 year-olds" (Ö6)

"By seeing from my brother at the age of four." (Ö21)

"In my primary school, my family and my teachers" (Ö23)

When the frequencies of the "Purpose of Internet Usage" category are examined, it is seen that the sub-themes of the most homework $(n=13)$ and games $(n=11)$ are selected and the frequencies are close to each other. Here are some of the answers students make about how they use the Internet and how they use it:

"For social networks, entertainment and homework." (Ö13)

"I use it for games, research and entertainment." (Ö17)

"Homework and play." (Ö18)

Looking at the "Reading Newspaper/Journal from the Internet" category a total of 22 respondents in 24 indicate that do not read newspapers/journals on the internet.

Some of the answers given by students about their reading of newspapers / journals on the internet are as follows:

"No" (Ö10)

"No. We are satisfied with what we learn from social networks." (Ö13)

"Yes" (Ö22)

Problems Encountered category is $n=27$ in total. Some of the answers to the problems encountered while using the computer and the internet are as follows:

"Someone I do not know sends me a message" (Ö3)

"Advertising is out." (Ö10)

"Computer and internet freezing and slowness" (Ö11)

Solutions to Problems Encountered category is $n=25$ in total. Some of the answers about finding solutions to problems encountered while using computer and internet are as follows:

"If I have a bad message, I will prevent it." (Ö3)

"By closing the ad, I find the solution by not watching." (Ö10)

"I find a solution by turning it off and on." (Ö11)

Social Media Problems category is $n=29$ in total. Some of the answers to the problems in social media platforms are as follows:

"Inappropriate senders, bad messages" (Ö5)

"The people we do not know send a request" (Ö11)

"I meet curses." (Ö21)

Unauthorized Photo / Video Sharing category is $n=27$ in total. It is seen that the frequencies of the "it was" $(n=12)$ and "it was not" $(n=15)$ main themes are close to each other. Some of the responses to an unauthorized photo or video sharing and response are:

"Yes. I complained to him." (Ö5)

"Yes. I followed him up and complained to the social media." (Ö18)

"Yes. I stole his reckoning." (Ö19) 
Receive an Irritating Message category is $n=24$ in total. Some of the answers to the disturbing message / commenting situation are:

"Yes. Profanity etc." (Ö3)

"Yes. Slang words." (Ö5)

"Yes. I received disturbing messages." (Ö10)

In Social Media Mockery category is $n=24$ in total. Some of the answers to the mockery in the social media are:

"No. It did not." (Ö2)

"Yes. I played him." (Ö5)

"It did not. I would throw spam if I were." (Ö22)

Internet Insulting category is $n=24$ in total. Here are some of the answers to the question of exposure on the Internet:

"I was not exposed, but I complained and complained about the fact that a page had bad sharing." (Ö4)

"Yes. By my friend." (Ö5)

"Yes. Usually in comments." (Ö19)

Capture of Social Media Account category is $n=24$ in total. Here are some of the responses to the seizure of your social media account:

"Yes. My friend's facebook account was played." (Ö4)

"Yes. My instagram account was stolen. Everyone sent a message for him to spam."

"Yes. They stole my close friend's facebook account. Mine was never stolen." (Ö23)

When we looked at 24 frequencies in total in the Encounter Cyberbullying category, 3 people stated that they were facing cyberbullying and 21 people said that they did not encounter cyberbullying. Some of the answers given by the students about their encounter with cyberbullying and their feelings are as follows:

"Yes, I did. I was very bad and complained." (Ö4)

"Yes, I was very upset, but I did not cry." (Ö5)

"No, I did not, but I was sorry if I met." (Ö10)

When we look at 24 frequencies in total in the Cyberbullying Result Situation category, 9 people know what their rights are in case of cyberbullying, 15 people do not know their rights. Here are some of the answers given by the pupils about what they will do in case of cyberbullying and their knowledge of their rights:

"I'll be careful. I do not know my rights." (Ö8)

"I do not know my rights, but I will respond." (Ö15)

"I complain to my obstacles." (Ö16)

When we look at 24 frequencies in the Situation to Know Rights category, it is seen that 18 people said that I complained to the cyberbullying person, 5 people said that I did not complain, and 1 person said that I did not encounter cyberbullying. Most of the students interviewed $(\mathrm{n}=18)$ seem to complain about the cyberbullying person. It is determined that a student who says "No" says that I am doing it myself.

Place of Complaint category is $\mathrm{n}=21$ in total. Some of the answers given by students about complaints and situations of cyberbullying and where to go are as follows:

"Yes. But I do not know where to apply." (Ö5)

"I do. Police appeal and close my account." (Ö12) 


\section{"I do. Police" (Ö24)}

\section{Conclusion and Discussion}

In this study, the opinions of the middle school students who are studying in Ereğli and their parents about internet usage were examined. Within the scope of the research, 24 students and 12 parents were interviewed and the data were collected through interviews.

According to the results obtained from the data, the following results were obtained: It was seen that the number of people who knew the concept of cyberbullying was 12 and the number of people who unknown was 5. Parents stated that children often use the internet for entertainment purposes and that there is a lot of internet use. They stated that they use computer and internet mostly for lessons and games. People who use the computer in the common use area are in the majority. Seven of the 12 respondents indicated that they did not use secure internet service. It has been observed that the vast majority of parents control their children's use of the computer, the use of the internet, what games or sites they enter on the internet. A large majority of parents said their children know and use educational content sites. It has been observed that the majority of the parents are aware of the problems their children face on the internet. It has been seen that the majority of the parents chose to take measures, complain and solve the problems they encountered by resorting to legal measures in case of their child encounters with cyberbullying.

It was seen that the number of students who knew the concept of cyberbullying was 5 and the number of students who unknown was 19. It is concluded that the majority of students do not know the concept of cyberbullying. It has been observed that the majority of students learn the use of computer and internet from their fathers and family members in their 5-6 years old. Parallel to the opinions of the parents, it is seen that students use the internet mostly for homework and play. It has been observed that a large majority of students do not read newspapers/magazines on the internet. It has been seen that the problems that students encounter while using computer and internet are mostly related to harmful software and hardware. It is seen that they encounter the problem of messages and friend requests from people they do not know most on social media platforms. It has been seen that a majority of people have complained when someone did share something they do not want. It has been observed that the majority of disturbing messages and comments in the form of abusive and slang sentences. It has been observed that the students did not know the rights of the majority in the case of encounter cyberbullying but they stated that they will complain to the police and related places.

\section{Suggestions}

Suggestions are given under the related headings based on the results obtained from the findings of the research.

\section{Suggestions for educators}

By giving informative seminars to students and parents about bullying, it is possible to be more conscientious and to make it easier for them to overcome the problems they face.

\section{Suggestions for parents}

In the interviews with the parents and students, the conclusion was reached that the conception of cyberbullying and the rights of cyberbullying are mostly unknown. The 
awareness of the parents about the cyberbullying and the informing and warning of the children on this issue will be helpful.

It is recommended to use a secure internet service to ensure that your children are in a more secure virtual environment. In the interviews, results reached the conclusion that the children of some of the parents did not know about the problems they encountered on the internet. It is suggested that the parents should spend time with their children to feel that they are with them at all times and to monitor and control the problems their children are facing. Thus, it will be possible to protect their children against future threats.

\section{Proposals for the researchers}

This study, which is carried out with secondary school students, can be done with primary and high school students and the internet usage of other students and problems in internet environment of students in the other age groups can also be determined.

\section{References}

Akbulut, Y. \& Erişti, B. (2011). Cyberbullying and victimization among Turkish university students. Australasian Journal of Educational Technology, 27(7), 1155-1170.

Baker, Ö.E. \& Kavşut, F. (2007). Cyber bullying: A new face of peer bullying. Eurasian Journal of Educational Research, 27, 31-42.

Blais, J. (2008). Chatting, Befriending, And Bullying: Adolescent Internet Experiences and Associated Psychosocial Outcomes. Doctoral thesis, Queen's University, Kanada.

Brown, K., Jackson, M. \& Cassidy, W. (2006). Cyber-bullying: developing policy to direct responses that are equitable and effective in addressing this social form of bullying. Canadian Journal of Educational Administration and Policy, 57.

Cross, E.J., Piggin, R., Douglas, T. \& Vonkaenel-Flatt, J. (2012). Virtual violence II: Progress and challenges in the fight against cyberbullying. London: Beatbullying.

Dilmaç, B. (2009). Psychological needs as a predictor of cyber bullying: A preliminary report on college students. Educational Sciences: Theory \& Practice, 9(3), 1291-1325.

Englander, E. \& Muldowney, A.M. (2007). Just turn the darn thing off: Understanding cyberbullying. Proceedings of Persistently Safe Schools: The 2007 National Conference on Safe Schools and Communities, USA, 83-92.

Görzig, A. \& Frumkin, L.A. (2013). Cyberbullying experiences on-the-go: When social media can become distressing. Cyberpsychology: Journal of Psychosocial Research on Cyberspace, 7(1), article 4.

Hinduja, S. \& Patchin, J.W. (2011). Cyberbullying: Identification, prevention, \& response. Cyberbullying Research Center. Access Date: 16 January 2017. http://cyberbullying.org/Cyberbullying-Identification-Prevention-Response.pdf

Kowalski, R.M. \& Limber S.P. (2007). Electronic bullying among middle students. Journal of Adolescent Health, 41(6), 22-30.

Kowalski, R.M., Limber, S.P. \& Agatston, P.W. (2008). Cyberbullying. Malden, MA: Blackwell. Access Date: 29 January 2017. http://onlinelibrary.wiley.com/doi/10.1002/9780470694176.fmatter/pdf

Li, Q. (2007a). Bullying in the new playground: Research into cyberbullying and cyber victimisation. Australasian Journal of Educational Technology, 23(4), 435-454.

Li, Q. (2007b). New bottle but old wine: A research of cyberbullying in schools. Computers in Human Behavior, 23(4), 1777-1791.

Manap, A. (2012). Secondary School Students and Cyberbullying: Instance of the Samsun City. Master thesis, Ondokuz Mayıs University Institute of Educational Sciences, Samsun. 
Mason, K.L. (2008). Cyberbullying: A preliminary assessment for school personnel. Psychology in the Schools, 45(4), 323-348.

Özdemir, M. (2010). Qualitative data analysis: A study on methodology problem in social sciences. Eskişehir Osmangazi University Journal of Social Sciences, 11(1), 323-343.

Özdemir, M. \& Akar, F. (2011). Examination of high school students' opinions on cyberbullying in terms of various variables. Educational Administration: Theory and Practice, 17(4), 605-626.

Raskauskas, J. \& Stoltz, A.D. (2007). Involvement in traditional and electronic bullying among adolescents. Developmental Psychology, 43, 564-575.

Slonje, R. \& Smith, P.K. (2008). Cyberbullying: Another main type of bullying? Scandinavian Journal of Psychology, 49, 147-154.

Steffgen, G. \& König, A. (2009). Cyber bullying: The role of traditional bullying and empathy. University of Luxembourg, Campus Walferdange, Research Unit Inside, Walferdange.

Tanrıkulu, T., Kınay, H. \& Arıcak, O.T. (2013). Cyberbullying sensibility scale: Validity and reliability study. Trakya University Journal of Education, 3(1), 38-47.

Tokunaga, R.S. (2010). Following you home from school: A critical review and synthesis of research on cyberbullying victimization. Computers in Human Behavior, 26, 277-287.

Yıldırım, A. \& Şimşek, H. (2013). Qualitative research methods in social sciences (Extended ninth edition). Ankara: Seçkin Publishing. 